\title{
Understanding Russian and Turkish State-National Interests in the Syrian Conflict through the Neo-Realism Paradigm
}

\author{
Mariia German, Tan Tan* \\ School of Government, Shanghai University of Political Science and Law, Shanghai, China \\ Email: ^tantan@shupl.edu.cn
}

How to cite this paper: German, M., \& Tan, T. (2021). Understanding Russian and Turkish State-National Interests in the Syrian Conflict through the Neo-Realism Paradigm. Open Journal of Political Science, 11, 706-720.

https://doi.org/10.4236/ojps.2021.114045

Received: September 24, 2021

Accepted: October 22, 2021

Published: October 25, 2021

Copyright $\odot 2021$ by author(s) and Scientific Research Publishing Inc. This work is licensed under the Creative Commons Attribution International License (CC BY 4.0).

http://creativecommons.org/licenses/by/4.0/

\begin{abstract}
The study is devoted to the analysis of Russian-Turkish interaction in the Syrian conflict under neo-realism concept. The Syrian crisis has become a kind of Russian-Turkish relations "barometer" in recent years. On the Syrian battlefield, Moscow and Ankara as unitary and rational actors both try to increase their relative power, which enables them to achieve their objectives mainly connected with prospects for national interests. The detailed analyses of the Russian-Turkish diplomatic negotiations and dynamics of joint military-political activities lead to the conclusion that despite competing for military-strategic, energy and geopolitical interests, both parties opt to jointly balance against common challenges. Being aware of the mutual necessity and adhering to the principles of "realpolitik", Russia and Turkey prefer to negotiate and act within the framework of widespread interests, where real and potential mutual benefits prevail over disagreements.
\end{abstract}

\section{Keywords}

Russia, Turkey, The Syrian Conflict, Neo-Realism

\section{Introduction}

It is Syria that has become an apple of discord, a point of rupture in RussianTurkish relations, characterized as "multifaceted strategic cooperation", which has demonstrated positive dynamics in almost all areas in recent years. The changing geopolitical situation in the Middle East has forced Moscow and Ankara to look for new policy approaches in this region, and the Syrian crisis has become a kind of Russian-Turkish relations "barometer" in the second decade of the $21^{\text {st }}$ century. 
As a result of a unique combination of internal and external factors in the Syrian crisis, a complex conflict node has formed, in which the interests of many state and non-state actors-local, regional and extra-regional intertwined. Turkey is a key actor in regional international relations and a guarantor of regional security, while Russia is a leading non-regional player and a key supporter of Bashar al-Assad. In this regard, the review of parties' national interests in the Syrian conflict indicates the degree of their involvement in Syrian politics, which largely determines the outcome of events.

This article focuses on Turkish national interests and its policy in Syria before Russian involvement as well as Russian strategy in the Syrian Arab Republic (SAR) in the context of Russia's national interests. Notwithstanding the Syrian issue is on the global agenda for about a decade and Russia and Turkey activities in Syria for an extended period, the problem of studying Russian-Turkish national interests in Syria in the context of neo-realism assessment has not been the subject of separate research in the academic.

Indeed, the national interests of Russia and Turkey in the Syrian direction are not identical. However, despite the conflict of interests, both parties prefer to interact pragmatically rather than engage in open confrontation. In this regard, the theoretical framework of neo-realism concept contributes to analyze the difference between Moscow and Ankara's motives in the Syrian conflict, and explain from the theoretical point of view why the parties prefer to jointly coordinate actions at the Syrian theater of war.

\section{Theoretical Background of Neo-Realism and Its Key Elements}

The complexity of the system analysis of the state-national interests related to the issue of which analytical paradigm is applied to assess international political processes. The problem of national interest attracted the attention of many thinkers, but as a key category, it arose primarily in the studies of political realism and neo-realism representatives. Through the separation of politics into the autonomous field of study, neo-realism was able to create what realism soughta working theory that allows analyzing the international system as a whole. Only within the framework of neo-realism the realistic point of view has formed a systematic approach, which is applied in the analytical framework of this paper.

Neo-realism arose in the late 1950 s of the $20^{\text {th }}$ century, and the completion of its formation in the late 1970s. It is a rather multifaceted phenomenon in modern political science, and it combines an impressive quantity of theories. It based on a synthesis of political realism (G. Morgenthau) and structural realism (K. Waltz). Waltz's "Theory of International Politics" (Waltz, 1979) and John Mearsheimer's "The Tragedy of Great Power Politics" are two main theoretical works for the neo-realism concept.

Neo-realists adhere to a structural approach in international relations. Originally they consider the mechanism of the international system functioning and 
only after they proceed to analyze other aspects related to it. Consequently, neo-realism is also called structural realism. The neo-realist approach is based on the same basic principles as classical realism, but some key concepts acquired distinct features in it.

According to the neo-realism theory, the international relations operate in anarchy conditions, what means that there is no central authority above states. Such conditions caused by a situation in which equal individuals drive "by competition, diffidence and glory" (Burchill et al., 2005). The leading rational actors in international politics are states, which strive for power to protect national interests, state security and preservation of the status quo in international relations.

In neo-realism, power remains a key element as in realism; however, the role of it has a bit shifted. If Morgenthau sees power as an independent and sole goal of the state, then K. Walz defines power as "a potentially useful tool" (Waltz, 1988). Accordingly, both lack of power and its surplus can theoretically pose a threat to state. In the neo-realists' picture of the world, power to some extent loses its sacred meaning, but it acquires more clear-cut features.

In relation to power there are two subdivisions of structural realism: defensive (K. Waltz) and offensive realism (J. Mearsheimer), the difference between which is in how much power is enough for each state. In the situation of disorder, states can never be sure about other states' intentions and thus, they possess the military capability and could act like offensive actors by "self-help" principle. In both cases balance is the result of a struggle for power, clashes between states seeking to expand their capabilities, and those who are more profitable prefer to maintain the status quo. At the same time, some defensive realists "argue that there is an offence-defense balance which almost always favors the defense, and thus works to dampen security competition. As such, balance is a force for peace" (Mearsheimer, 2006).

The foreign policy activity of states is inevitably accompanied by a search for security. Hence, the central category among neo-realists is not power itself, but security and the desire for it, which, according to Waltz, is the ultimate goal of the state. It is the need for security that determines the interaction of states in the international relations system (IRS). To achieve their security, revisionist states are building up their power, status quo states store its ratio. The source of the choice between "offence" and "defense", within the framework of the theory of neo-realism, should be sought not in the internal properties and characteristics of the state, but in the situation that has developed on the international stage.

State entering into international relations builds its foreign policy goals on the basis of an ideal and its own interests. Thus, state interests ${ }^{1}$ and intentions are another essential components of neo-realism.

National interest is an abstract and subjective category, since its parameters

${ }^{1}$ In this article, the authors use the concept of "national interest" based not on the ethnic component, but on the state one, considering national and state interests as complementary concepts. The notion of "state interest" to a large extent determines the semantic structure of "national interest". In this regard, authors also use the idea of "state-national interests". 
are determined by the picture of the world and the system of values that prevails in a given society and state. State national interests are formed in accordance with the geopolitical situation and resource capabilities of the state with considering intersection of many intertwining, interconnected, mutually complementary, conflicting, multidirectional structures, interests, preferences, etc.

The prime motive of state is survival and states' first concern is to maintain their relative position in the international system. In this regard, in the concept of realists and neo-realists the structure of national security is considered as a derivative of the system of national interests. By "national security", the neorealist school understands measures aimed at ensuring the physical survival of the state as a system within the framework of the IRS (protection of sovereignty, territorial integrity, adequate reaction to internal and external threats, etc.). In order to survive, states seek power and ally. Besides, states also persistently seek other valuable goals, such as advantages, peaceful coexistence, wealth, independence, etc.

State security has a very close relation with another key finding of the neo-realism-security dilemma. The unintentionally untwisting distrust that arises among countries as a result of balancing and joining the strong leads to a security dilemma. It can be described as an involuntary escalation of mistrust and rivalry between countries when one of them takes actions that it considers defensive, while other players see them as a threat, which ultimately starts a new cycle of balancing and joining a strong actor or group of actors. Indeed, most of the actions that a country takes to increase its security reduce the security of other states as they lose their relative power. In the world of zero-sum games, it is difficult for a state to improve its position without constituting a threat to other states. The reason states behave in this way is because they strive to become strong, seeing strength as an indispensable condition to guarantee their survival, which all countries are most interested in.

National interests are revealed as they are implemented in the state politics. State interests are consolidated in official documents and unofficial statements by scientists and experts. The first group of documents includes doctrines, strategies, concepts that are created and published by the governments of most countries. The second one includes publications and speeches by leading experts in the field of politics and international relations. In order to realize goals states demonstrate active actions. That is why it is necessary to consider the layer of Turkish-Syrian and Russian-Syrian relations before the start of the phase of active interaction between Moscow and Ankara in the Syrian crisis. Thus, neo-realism contributes to reveal and determine Russian and Turkish state-national interests in Syria, both states structural positions as well as dimension of their politics in the Syrian direction.

\section{Turkish National Interests and its Policy towards Syria before Russian Military Involvement into Syrian Conflict}

Since the Justice and Development Party (AKP) came to power in 2002, Ankara 
has taken a more open friendly foreign policy towards the Middle East countries, building friendly relations with regional states in the framework of the "Zero Problems with the Neighbors" (ZPwN) doctrine. Syria is an exceptional example of this doctrine ${ }^{2}$. Historically, there are three significant barriers between Turkey and Syria: the disputed province of Alexandretta ${ }^{3}$, which is under the control of Turkey but claimed by Syria; close relations between Damascus and the Soviet Union in the Cold War while Turkey was part of NATO; and Syrian support for Kurdish rebels in Turkey (Perchoc, 2016) ${ }^{4}$.

However, the relations improved significantly after Bashar al-Assad assumed the power in 2000 and Recep Tayyip Erdogan became prime minister in 2002. Despite the existence of contradictions, both sides sought to avoid open confrontation. Turkey saw Syria as a gateway to be involved in the Arab affairs; thus Ankara and Damascus cooperated through joint cabinet meetings, combined military drills, and a free trade agreement (Yilmaz, 2013). “Turkish exports saw a threefold increase between 2006 and 2010, rising to 1.85 billion dollars and making Syria Turkey's seventh largest market in the Middle East and North Africa. Syria's exports to Turkey rose from 187 million dollars in 2006 to 662 million dollars in 2010." (D’Alema, 2017)

Moreover, in September 2009, Turkey and Syria signed an accord of visa liberalization. In 2011 both countries agreed to build the "friendship dam" on the Asi River (Davidov, 2011), what was a somewhat problematic issue during an extended period. Furthermore, both countries decided to organize the common Council of Ministers. Hence, Syria was the most successful example of the "zero problems" doctrine, and during the first decade of the 21st century, Ankara was able to transform its complicated relationship with Damascus into strategic cooperation (Bağci, 2015).

The Arab Spring demanded the Turkish leadership to reconsider its regional politics approach and, in particular, Turkish-Syrian relations. When, against the backdrop of mass protests of the Arab Spring, a civil war swept Syria, which has the longest border with Turkey, Ankara had to make a critical choice to which conflict side it should provide support. The AKP government had significant investment in building good neighbourly relations with Bashar al-Assad over the past decade (Dalacoura, 2012).

${ }^{2}$ Turkey was concerned about the war in Iraq that began in 2003, which led to the threat of strengthening Kurdish separatism, so the development of relations with its neighbors, primarily with Iran and Syria, remained a priority. For this reason, even in 2010, when the Middle East was engulfed by a wave of protests, Turkey behaved quite restrained.

${ }^{3}$ After the collapse of the Ottoman Empire, a territorial dispute arose between Syria and Turkey over the Alexandretta province, which was transferred to the Syrian State of Aleppo as part of the French mandate. However, in 1936, Mustafa Kemal Ataturk started fighting for this area, which was designated by him as Hatay. On the eve of the Second World War, Western countries decided to handle Hatay to Turkey. This solution caused serious problems in Turkish-Syrian relations in 20th century, which have not been resolved until now.

${ }^{4}$ President Hafez Al-Assad welcomed the leader of the Kurdistan Workers' Party (PKK) Abdullah Öcalan, who was staying in Damascus for nearly 20 years (1979-1998). Syria's expulsion of the PKK leader Abdullah Öcalan, in 1998, cleared the most significant cause of friction between Turkey and Syria. Nowadays, he is imprisoned in Turkey. 
Turkey's historical and political ties with Syria make the situation individual and different from Ankara's relations with other countries experiencing the Arab Spring. According to Professor Bağci, Turkey had three central national interests in Syria: to prevent establishing any Kurdish government in Northern Syria; to control radical Islamists group in Syria; to have a new government in Syria which can be controlled by Turkey (Bağci, 2015). Consequently, Turkey's attitude was mainly shaped by these three national interests in Syria. "The Turkish government wanted to prevent an environment that would lead to the dissolution of the Syrian state that would trigger ethnic and sectarian conflict and its spillover effects to Turkey" (Ayman, 2013), what can be identified as a transformation of Syrian crises into a Turkey's domestic matter of concern.

Those objects are also confirmed in the report of European Council on Foreign Affairs: "Turkey's Syria policy has been driven by a domestic political need to merge the values of the AKP government with Turkish national interests, regarding stability, preventing a regional war with sectarian spillover, and (crucially) limiting the impact of the weakening of Syria's central state on Turkey's domestic Kurdish conflict." (Yilmaz, 2013)

Overall, Turkish national interests in Syria can be divided by following parameters.

\subsection{Military-Strategic Interests}

The task of the Turkish leadership is to ensure the security of the Turkish borders. It was in the Syrian direction that Turkey encountered two forces: Islamic State of Iraq and the Levant (ISIS) and People's Protection Units (YPG). The establishment of Islamic State in the neighborhood Syria was a direct threat for Turkey security. At the end of July 2015, Turkey joined the Global Coalition against DAESH.

Furthermore, Turkey primary concern is to prevent the rise of an autonomous Kurdistan in Syria under the aegis of the Democratic Union Party (PYD). This new entity would indeed probably provide logistical support for the Kurdistan Workers' Party (PKK)'s activities in Turkey. Ankara is ready to cooperate with Iran and even Damascus, which are also engaged in preventing a PKK/PYD influence in the region.

Additionally, practical Turkey's assignments resolved with reliance on loyal Turkish groups. The creation in the north of the SAR along the entire borderline with Turkey a security belt (50-70 km deep) not controlled by the Syrian government, not occupied by Kurdish forces and ISIS fighters is one of the central objectives (Khodynskaya-Golenishcheva, 2019).

Another problem-refugee influx (UNHCR, 2020). The Syrian crisis has not just challenged Turkey's financial capabilities but has also negatively affected its security and created a difficult social situation in the south-eastern regions of the country, where sporadic incidents of violence have occurred (Idiz, 2015). 


\subsection{Energy Interest}

Energy factor is a vital element of the Middle East regional diplomacy. In 2009, Qatar came up with a project to lay a trans-regional pipeline through the Sunni states, Qatar-Saudi Arabia-Jordan-Syria-Turkey in order to ensure gas supplies to Europe. Turkey was assigned a unique transit role in this project that significantly strengthened its geopolitical positions. However, President B. Assad realized that Qatar's project is contrary to Syria's interests and does not contribute to the advancement of bilateral relations with Russia, a principal European gas supplier. Hence he refused to implement Qatar's gas plan, thereby turned some states, including Turkey against himself.

The SAR had its own energy transit plan, reinforcing Syria's geopolitical role as an energy corridor ${ }^{5}$. On 25 June, 2011 in Bushehr, an agreement was signed on the construction of a new gas pipeline, Iran (Assalueh)-Iraq-Syria, the so-called "Islamic Pipeline". The Islamic Pipeline was seen by the Arabian monarchies and Turkey not only as a severe economic competitor but also in the context of interfaith (Sunni-Shiite) contradictions-as a Shiite gas pipeline from Shiite Iran through Iraq with its Shiite majority and friendly to Shiites of Alawite Syria led by B. Assad (Valiakhmetova, 2016). It is possible that in this regard, the Turkish leadership has revised its position on Damascus and relied on more Turkish loyal opposition circles that would not threaten to strengthen Turkey's transit positions.

\subsection{Geopolitical Interest}

In a geopolitical context, there is another reason for Ankara's involvement in the Syrian crisis: Turkey authorities "realized that the U.S. would occupy one of the key territories in this conflict, and if Turkey does not support its ally-NATO, then it will forever lose the support of one of the most powerful states in the Western world". Besides, Turkey probably did not want to establish American control as one of the most influential parties to the conflict over some border territories at its completion, also wishing to strengthen its position in Syria, and to do this in alliance with the U.S. seemed a more promising scenario (Avatkov, 2019).

Further, a potential conflict was necessary for testing modern Turkish weapons. A large-scale campaign to support the Syrian anti-government forces, three military operations made it possible to examine the effectiveness of the Turkish military arsenal (Kasapoglu, 2019) and strengthen Ankara's regional position.

After the beginning of the crisis, Turkish policy towards Syria has gone through three stages. From the first days of situation destabilization, Erdogan

\footnotetext{
${ }^{5}$ The SAR's strategic advantage is its geographical location in the Eastern Mediterranean region, in the center of the Middle East, which inevitably increases the geopolitical importance of Syria. The discovery of oil and gas reserves in the Levant basins has increased the regional and global importance of the Syrian energy sector. In this context, Bashar al-Assad formed a new regional energy strategy, in which Syria was given a central place.
} 
maintained a dialogue with both Damascus and the opposition. In April 2011, Davutoğlu visited Syria and proposed three suggestions: the abolishment of the state of emergency, giving national identity to Kurdish population and prevent any military intervention to protests (Bağci, 2015).

From March to September 2011, the Turkish administration repeatedly tried to convince B. Assad to carry out reforms and take the necessary measures to conclude the protracted domestic political crisis. By November 2011, Erdogan called on the Syrian President to step down. After Turkish leadership realized that B. Assad would not give up power, it took the side of the opposition. Ankara hosted the first meetings of the Syrian National Council in Istanbul in $2011^{6}$, allowed to establish the Free Syrian Army (FSA) headquarters in the South-East of Turkey, and in 2012, became the head of the Friends of Syria Group, which task was to exert maximum pressure on the Syrian government and support the opposition. In the course of these steps, Turkey has become a key external actor in the Syrian crisis.

On 22 June, 2012, Syrian Air Defence shot down a Turkish aircraft F-4 fighter over the territorial waters of Syria. Unwilling to give reasons for Turkey's direct intervention in the war, Bashar al-Assad publicly apologized for the incident (Vasiliev, 2018). Notwithstanding, Ankara called on NATO for military assistance. "It was important to internationalize the Syrian crisis. It means that the Syrian problem became directly related to Turkish security and sovereignty rights, which is a member of NATO.” (Bağci, 2015). Besides,

Russian military intervention initially focused on the Aleppo-Lazkiye line that Turkey suggested a "safe zone" and on the supply line between Turkey and Aleppo. In this sense, it was visibly against Turkish designs in Syria. As a result, the Turkish strategy to form a "safe zone" on Aleppo-Lazkiye line was destroyed. (Rüma \& C, elikpala, 2019)

\section{Russian Strategy in Syria in the Context of Russia's National Interests}

The Soviet-Syrian alliance during the cold war of the 20th century created a solid foundation for the advancement of the Russian-Syrian dialogue in the 21st century. For a long period, Syria was a reliable customer of the Russian military-industrial complex (missile systems, aircraft and air defense systems) ${ }^{7}$, and also remained one of the countries in the Middle East where Moscow maintained its geopolitical positions.

Since the beginning of the political crisis in Damascus in 2011, Russia has

\footnotetext{
${ }^{6}$ The Syrian National Council (SNC) is based in Istanbul. It has emerged as the main political opposition to the official Damascus' regime and is seeking international recognition as the legitimate representative of the rebels, despite splits in its Syrian fractions. The Syrian Muslim Brotherhood plays a significant role in this process.

${ }^{7}$ It is impossible to confirm these figures by official statistics. In the database of the Federal Customs Service, most of the Russian exports to Syria pass under the secret code 22SS. Exports from Russia to Syria. Ru-Stat, https://ru-stat.com/date-Y2013-2015/RU/export/SY.
} 
been seriously concerned about the stability of the Assad regime and advocated an intra-Syrian dialogue. Russian diplomats advised Damascus to negotiate with the opposition in order to prevent an uprising. Moscow, however, did not back its friendly advice with pressure or disincentives. Moreover, Russia did not perceive Assad to be an indispensable ally-Russian President Vladimir Putin did not even talk to Assad by phone until 2013-Moscow continued to send weapons and sign new contracts with Syria (Trenin, 2014).

Over the all period of destabilization in Syria, Russia has tried to cooperate with Western countries and the U.S. in the diplomatic arena to find a solution. For example, on 30 June, 2012, Moscow jointly with Washington, organized the Geneva-1 Peace Conference, at which the parties failed to reach agreements. Later in 2013, Putin offered Obama a plan to eliminate Syria's chemical weapons and persuaded Assad to accept it. In January 2014, the Geneva-2 Conference on Syria again convened on the initiative of the Russian and the U.S. Foreign Ministers. At the UNSC Russia has repeatedly voted against the resolution on the situation in Syria. Thus, throughout the entire period before the Russian military intervention, Moscow appealed to the diplomatic levers of resolving the Syrian conflict.

As the conflict has become internationalized, Russia has taken a more intense course towards Syria. The main concern for Moscow was the possible intervention of the West or Arab countries in Syria to replace the legal Assad's government with pro-Western authorities. Moscow was shocked by the events in Libya in 2011 when its decision not to veto a UNSC resolution imposing a no-fly zone on the country created an opportunity for NATO military intervention and regime change in the country. Russia took the case of Libya as a precedent that should not repeat in Syria; therefore, Moscow rejected any proposals in the UNSC related to the condemnation of the legitimate Syrian government (Trenin, 2014).

On 30 September, 2015, at the request of President Bashar al-Assad, Russia launched a military operation in Syria. The military objective of the operation was to provide air support to Syrian government forces in their fight against the Islamic State terrorist group. Russia is the single country that uses force in Syria legally. It can be done either with a UN mandate that no one has or at the request of the legitimate Syrian government, which only Russia has. However, Russia, like all regional and non-regional actors, also has its interests in Syria, which are conditioned by a whole set of interrelated goals and objectives.

\subsection{Military-Strategic Interest}

Russia's military and strategic interests in Syria base on security. "Russia views combating international terrorism as an essential government task and a key priority for international security"-declared in Foreign Policy Concept of the Russian Federation (Ministry of Foreign Affairs of the Russian Federation, 2016). In 2015, about $70 \%$ of the SAR's territory was under the control of the 
armed opposition (non-governmental and irregular armed groups) and terrorist groups (Khodynskaya-Golenishcheva, 2019). The military objectives of the Russian presence in Syria are to eradicate radical groups and ISIS which may threaten Russia's security if they succeed in the Middle East (Brigea, 2020). Indeed, visa-free regimes with Turkey and many former Soviet republics have increased the risk of radical elements migrating to Russian territory.

\subsection{Geopolitical Interest}

Russia's geopolitical interests in Syria connected to the Russian military presence in the Mediterranean Sea.

First, "given the tension in Russian-American relations and the fact that the U.S. 6th flotilla, which can lock up the Russian fleet in the Black sea if necessary, Russia's presence in the Mediterranean is important and necessary (Satanovsky, 2015)." So, the military task is to preserve Russia's single mid-sea military base. In December 2012, Russian policymaker recognized that "in case of Assad's regime change, the new authorities unlikely will keep Russian economic projects, continue to lease the base in the port of Tartus and remain Russian partners in the field of military-technical cooperation." (Shumilin, 2013)

Second, several new Russian steps in the Middle East region are an attempt to strategically balance forces that will make difficult for the U.S. to ensure its interests. There is a definite signal from Moscow: Russia is still a power to reckon. Thus, "Russia has two broad strategic objectives in the Syrian conflict: challenging U.S. dominance in world affairs and aiding Assad in the fight against Islamist radicals." (Trenin, 2014). So, Russia must maintain presence and influence in the country and the region under any legal regime in Damascus.

Third, as in the case with Turkey, the military operation of Russian troops in Syria was also a platform for demonstrating the Russian military power and military equipment. "Interest in domestic weapons has always been high, but after Syria, it has grown even more. The situation in the SAR certainly allowed potential customers to look at the combat use of some samples." (Rostec, 2019). Additionally, the Chief of the General Staff of the Russian Armed Forces (RAF), General Valery Gerasimov emphasized that

The RAF is gaining combat experience in Syria. They had a unique opportunity to test new samples of weapons and military equipment in difficult climatic conditions. It is necessary to continue to generalize the experience of using the means of armed struggle in the Syrian campaign, to learn lessons for their improvement and modernisation. (Valeri, 2017)

\subsection{Economic Interest}

Some Russian analysts addressed to Moscow's economic interests in the SAR considering that foreign policy designed to serve or at least not contradict to the state's economic interests. However, concerning Syria, Russian economist Vladislav Inozemtsev questions this argument. He notes that Syria is a long-standing debtor 
since the Soviet times, to which Russia wrote off $73 \%$ of the debt, the remainder of which it obliged to return not with money, but with its goods. He also critically questions the profitability of Russian military-technical supplies to Syria, since "no more than $20 \%$ paid for all this with live money." (Alien, 2012). According to the Russian export centre, in 2019, the SAR's ranks $89^{\text {th }}$ in Russian exports, $132^{\text {nd }}$ in imports, $76^{\text {th }}$ in Russia's non raw material and non energy export, and $103^{\text {th }}$ in Russia's trade volume (Russian Export Center, 2020). Therefore, in the situation with Syria, political objectives prevail over economic interests.

Abstracting from the official Russian political discourse, in addition to the above factors, Russian experts identify the energy factor as an integral part of the modern international relations, which is one of the fundamental elements that determine the Middle East strategy of the Russian Federation.

\subsection{Energy Interest}

The West endeavoured to displace Russian gas from European markets and began to consider the Persian Gulf countries, Qatar and the Kingdom of Saudi Arabia (KSA), as a resource base, as well as the prospect of implementing the Qatari gas pipeline. Meanwhile, the U.S. plans to supply Europe with shale gas also undermine Russia's position as a major energy supplier. In the Syrian project "Islamic Pipeline", a unique role was assigned to Russia, since the export of Iranian and Syrian gas to Europe planned to carry out through the Russian-leased Syrian port of Tartus (Valiakhmetova, 2016). Furthermore, "the agreement between Soyuzneftegaz and the government of Syria on the creation of a new energy route through Iraq is another important reason why Russia needs to be present in Syria. If this route could be secured, it could become a new alternative to the Gulf countries for Europeans." (Bağci, 2015)

That is why the possible impact of Russian military involvement in Syria in Moscow's energy policy is an essential factor. The coincidence of Moscow and Damascus' energy interests contributes to strengthen their relations. Therefore, in the "big energy game of the Middle East", Russia relies on B. Assad.

\section{Applying the Neo-Realism Theory}

In consonance with neo-realism, IRS relies on permanently changing global balance of powers. The IR structure actively influences the content and the extent of national sovereignty, as well as the formulation of the national interests. The changing geopolitical situation in the Middle East and the constant shifting of the balance of power between regional and non-regional/extra-regional actors have led both Russia and Turkey to integrate into the Syrian crisis.

The first concern of the state is to maintain a relative position in the anarchical international system (Waltz, 1979) without "government of governments" (Mearsheimer, 2006). Indeed, the Middle East region, given the presence of three leading regional actors-Turkey, the KSA, and Iran, as well as key extra-regional actors-the U.S. and Russia, is in a constant state of geopolitical positions redi- 
stribution.

The only way to guarantee security in the anarchical global system is to protect the state's national interests and increase its power. Despite the fact that relations with Syria were significantly improved in the 20th century, the Turkish leadership was acknowledging the new regional situation, revised its Middle East strategy. Taking into account its own interests, the energy factor, and above all the priority issue of security, as well as being an ally of the U.S., Ankara has made a bet on the Syrian opposition circles. Turkey's relative position in the Middle Eastern Affairs was connected with supporting Syrian opposition (by hosting the FSA and the Syrian National Council). It was recognized by the Turkish administration as a mechanism to strengthen the regional geopolitical role, implement Turkey's will to engage in grand diplomacy, and maintain close ties with the U.S.

Neo-realism asserts that some states secure relative position through helping allies. The Russian case is a good example. It was possible to avoid the collapse and final erasure of B. Assad's Syria from the world map due to Russian intervention "from the air" and Iranian support "on the ground" for B. Assad's government.

By entering the civil war in Syria at the request of the B. Assad on 30 September, 2015, Moscow changed the course of the war, strengthened the positions of the ruling regime and secured Russian relative position in global politics. The primary intention of the Russian Federation is to ensure foreign policy and, as a consequence, internal security. The B. Assad's government is a friendly regime towards Russia, and in case of its collapse, Russia's position in the Middle East could significantly weaken. In this regard, Moscow has put forward a stable position within the framework of the international law principles, based on which the government should deal with terrorists on the territory of its own country. The legitimate government is President B. Assad's apparatus. Concerning Syria, Kremlin is guided by political perspectives rather than economic ones. Military and strategic tasks correlated to counter-terrorism, humanitarian activities, as well as security mechanisms, including energy, come to the fore.

In neo-realism, states can never be sure about the intentions of other states. Intentions are in the minds of decision-makers, and they are especially challenging to discern, for instance, "jet crisis" in Russian-Turkish relations. Lack of communication and uncompromising perspectives on Syrian crisis between parties led to freezing relations. Though, at the same time, temporary deterioration of Russian-Turkish relations from September 2015 to June 2016 was a catalyst for the importance of their partnership. Moscow and Ankara realized that they are complicated but necessary partners for each other. Such partners can create much trouble, but they are valuable because of their political course independence from other influential actors, appreciation of each other's national interests, and recognition of the necessity to coordinate positions.

Besides, in IRS states' top aims are survival and national security, and other 
purposes (economic prosperity, human rights, etc.) are secondary because if a state does not survive, it cannot pursue other goals. The principal aim of the Russian Federation is to ensure its foreign policy and, as a consequence, internal security. Changing B. Assad's regime which is friendly to Russia and under the onslaught of terrorism would turn Syria into a terror polygon that would increase the risk of radical elements migration to the Russian territory. The establishment of Islamic State and YPG activism in the neighborhood Syria was a direct threat for Turkey's security. Relying on the opposition groups loyal to Ankara, Turkey was solving security dilemma by a practical task: creation of security belt in the North of the SAR along the entire border line with Turkey.

All states possess some offensive military capability and develop more offensive military capabilities to ensure their security and foreign interventionism as a means of increasing their relative power. Furthermore, the state has a strong incentive to launch a preventive war against the challenger to halt its rise. For this reason, Ankara refused from the policy of containment and carried out three military operations in the border areas of Syria. In the course of military actions, Turkey demonstrated its military power, ability to secure its borders, prevented the emergence of Kurdish unity, confirmed the relative independence of its foreign policy from the U.S. and strengthened regional geopolitical positions. In the Syrian crisis, Russia adhered to the principle of "strike for an appropriate amount of power" (Mearsheimer, 2006), which enabled to achieve the military objectives of the Russian presence in Syria: to support B. Assad and destroy radical groups and ISIS. Syria was a platform for the Kremlin to return in the Middle Eastern Affairs and demonstrate Russian military power and military equipment.

\section{Conclusion}

The interests of Russia and Turkey in the Middle East are determined by a complex set of objective factors combined with the peculiarities of self-perception and self-positioning in the international arena. Given the fragmentation of international relations in the Middle East, conflicts, instability, both Moscow and Ankara are building their own vectors of Syrian politics based on their state-national interests.

It is the position of neo-realism that is helpful to interpret the parties' approaches to the Syrian crisis, as well as explain how the parties seek cooperation in the presence of disagreements. All states pursue a rational policy; therefore, they always strive to solve problems that correspond to national interests, which are subjectively interpreted from state to state. The contradiction between national interests leads to rivalry, which in turn encourages states to take action against each other in order to correct, as they believe, the imbalance of power that has arisen between them. However, the success of the state's foreign policy depends not only on how clearly and unambiguously the national interests are formulated but also on a clear understanding by the leadership of the ways and means of realizing these interests, including options for cooperation. 
Thus, case analysis demonstrates that in Syria, Russia and Turkey are neither inextricably linked by a unity of military-strategic, geopolitical, energy goals and objectives, nor by coinciding interests or strong trusting relations. The basis of their cooperation is the understanding that without interaction none of the parties can succeed. Russia is the only power with which, despite sharp contradictions and distrust, Turkey can find some understanding of the implementation of its goals. Russia without Turkey, and even more without its dialogue with the opposition, can also get bogged down in many problems in Syria and face certain risks. In a number of areas, both Russia and Turkey are ready to promote partnership and cooperation, since it creates the conditions for the most effective guarantee of both parties' national interests, considering their contradictory nature.

\section{Acknowledgements}

Preparatory research for this article is supported by Shanghai University of Political Science and Law "2020 Research Project” (No. 2020XJ06).

\section{Conflicts of Interest}

The authors declare no conflicts of interest regarding the publication of this paper.

\section{References}

Alien, V. (2012, December 24). Why Do We Need Syria. Russian International Affairs Council. http://old.russiancouncil.ru/blogs/riacmembers/?id_4=276

Avatkov, V. (2019). Turkish Republic. Foreign Policy: From 2002 to 2018 (p. 83). Yurayt Publishing House.

Ayman, S. G. (2013). The Arab Upheavals and the Turkish Perception Vis-à-Vis the West. Arab Studies Quarterly, 35, 305-323. https://doi.org/10.13169/arabstudquar.35.3.0305

Bağci, H. (2015, December 7). Strategic Depth in Syria-From the Beginning to Russian Intervention. Valdai Papers.

https://valdaiclub.com/a/valdai-papers/valdai-paper-37-strategic-depth-in-syria-from-t he-beginning-to-russian-intervention/

Brigea, D. (2020, July 20). What Are Russia's Interests in Syria Leading to. Middle East Monitor.

https://www.middleeastmonitor.com/20200720-what-are-russias-interests-in-syria-lea ding-to/

Burchill, S., Linklater, A., Devetak, R., Donnelly, J., Paterson, M., Reus-Smit, C., \& True, J. (2005). Theories of International Relations (p. 41). Palgrave Macmillan.

D’Alema, F. (2017, October 28). The Evolution of Turkey's Syria Policy. Instituto Affari Internazionali Working Papers.

https://www.iai.it/en/pubblicazioni/evolution-turkeys-syria-policy

Dalacoura, K. (2012). The 2011 Uprisings in the Arab Middle East: Political Change and Geopolitical Implications. International Affairs, 88, 63-79.

https://doi.org/10.1111/j.1468-2346.2012.01057.x

Davidov, P. (2011, February 6). Syria and Turkey Will Build a 'Friendship Dam' on the Oront River. RIA News. https://ria.ru/20110206/331015485.html 
Idiz, S. (2015, May 20). Attacks on Syrians in Turkey Increasing. Al-Monitor. http://www.al-monitor.com/pulse/originals/2015/05/turkey-attack-on-syrians-in-count ry-on-the-rise.html

Kasapoglu, C. (2019, October 25). Turkey's Military Capacity Turned the Tables in Syria. Anadolu Agency.

https://www.aa.com.tr/en/analysis/turkeys-military-capacity-turned-the-tables-in-syria $\underline{/ 1626106}$

Khodynskaya-Golenishcheva, M. (2019). Syria: The Difficult Path from War to Peace. Multilateral Diplomacy of the Syrian Settlement (p. 101). Arbis Publishing House.

Mearsheimer, J. (2006, July 31). Structural Realism. Mearsheimer. http://mearsheimer.uchicago.edu/pdfs/StructuralRealism.pdf

Ministry of Foreign Affairs of the Russian Federation (2016, December 1). Foreign Policy Concept of the Russian Federation (Approved by President of the Russian Federation Vladimir Putin on 30 November 2016).

https://www.mid.ru/en/foreign_policy/official_documents/-/asset_publisher/CptICkB6 BZ29/content/id/2542248

Perchoc, P. (2016, January 31). Turkey and Syria: A Struggle on Two Fronts. Briefing European Parliamentary Research Service.

https://www.europarl.europa.eu/RegData/etudes/ATAG/2016/573925/EPRS_ATA\%28 2016\%29573925_EN.pdf

Rostec. (2019, March 13). New Russian Records on the World Arms Market. Rostec. https://rostec.ru/news/novye-rekordy-rossii-na-mirovom-oruzheynom-rynke/

Rüma, I., \& Cęlikpala M. (2019). Russian and Turkish Foreign Policy Activism in the Syrian Theater. Uluslararasi Iliskiler, 16, 65-84. https://doi.org/10.33458/uidergisi.588930

Russian Export Center (2020, November 20). Syria. Russian Export Center. https://www.exportcenter.ru/international_markets/world_map/Arabia/Syria/

Satanovsky, E. (2015, September 30). In Syria, We Are Fighting for Russia. Fontanka. https://www.fontanka.ru/2015/09/30/144/

Shumilin, A. (2013, January 31). Russia and the Problem of Syria. Russian International Affairs Council. https://russiancouncil.ru/analytics-and-comments/analytics/rossiya-i-problema-sirii/

Trenin, D. (2014, June 9). Russia’s Interests in Syria. Carnegie Moscow Center. https://carnegie.ru/2014/06/09/russia-s-interests-in-syria-pub-55831

UNHCR (United Nations High Commissioner for Refugees) (2020, November 25). Syria Regional Refugee Response. United Nations High Commissioner for Refugees.

Valeri, G. (2017, March 13). The World Is at the Brick of War. VPK News. https://www.vpk-news.ru/articles/35591

Valiakhmetova, G. N. (2016). The Syrian Crisis as a Reflection of Trends in the Development of Global Energy Policy. International Relations, 11, 81-90.

Vasiliev, A. (2018). Russia's Middle East Policy: From Lenin to Putin (p. 539). Tsentrpolitgraf Publishing House.

Waltz, K. (1979). Theory of International Relations (p. 126). McGraw Hill.

Waltz, K. (1988). The Origins of War in Neorealist Theory. Journal of Interdisciplinary History, 18, 615-628. https://doi.org/10.2307/204817

Yilmaz, N. (2013, June 19). Syria: The View from Turkey. European Council on Foreign Relations. https://www.ecfr.eu/article/commentary_syria_the_view_from_turkey139 